\title{
Impact of Foliar Application of Various Forms of Silicon on the Chemical Composition of Sugar Beet Plants
}

\author{
Arkadiusz Artyszak $^{1}$ (1) Małgorzata Kondracka $^{2}$ (1) - Dariusz Gozdowski ${ }^{1}$ (i) \\ Alicja Siuda ${ }^{1}$ (i) Magda Litwińczuk-Bis ${ }^{1}$ (i)
}

Received: 9 May 2020/Accepted: 26 October 2020/Published online: 11 March 2021

(C) The Author(s) 2021

\begin{abstract}
The effect of marine calcite, a mixture of orthoand polysilicic acid as well as orthosilicic acid applied as a foliar spray on the chemical composition of sugar beet leaves in the critical phase of nutrient supply (beginning of July) but also leaves and roots during harvest time in 2015-2016, was studied. The content of silicon in the leaves ranged from 1.24 to $2.36 \mathrm{~g} \mathrm{~kg}^{-1} \mathrm{~d} . \mathrm{m}$. at the beginning of July, $3.85-5.34 \mathrm{~g} \mathrm{~kg}^{-1}$ d.m. during harvest and $2.91-4.20 \mathrm{~g} \mathrm{~kg}^{-1}$ d.m. in the roots. The foliar application of silicon caused a significant increase in the content of magnesium and calcium in leaves (in July) as compared to the control. The sugar beet consumes approx. $75 \mathrm{~kg} \mathrm{Si}$ $\mathrm{ha}^{-1}$, which is almost 3.5 times more than $\mathrm{P}$ and $20 \%$ more than $\mathrm{Mg}$ thus proving its importance for its species. About $70 \%$ of the silicon taken up by sugar beet is stored in roots and $30 \%$ in leaves. The pure sugar yield is most favorably influenced by two- and threefold foliar application of the product containing silicon in the form of orthosilicic acid stabilized with choline, and a threefold mixture of orthoand polysilicic acid. The increase in the pure sugar yield is not the result of a change in the chemical composition of sugar beet plants, but their more efficient functioning after foliar application of silicon under stress conditions caused by water shortage.
\end{abstract}

Keywords Beta vulgaris L. Macronutrients · Pure sugar yield $\cdot$ Silicon uptake

Arkadiusz Artyszak

arkadiusz_artyszak@sggw.edu.pl

1 Institute of Agriculture, Warsaw University of Life SciencesSGGW, Warsaw, Poland

2 Łukasiewicz Research Network-New Chemical Syntheses Institute, Puławy, Poland

\section{Introduction}

The research results indicated a beneficial effect of the use of silicon foliar application on the quantity and quality of yield of a great number of agricultural plant species grown in Europe (Artyszak 2018; Laane 2018). A positive effect of silicon foliar application was noted in various agricultural crops (Table 1).

Terrestrial plants contain from 0.1 to $10 \%$ silicon in dry matter (d.m.) (Currie and Perry 2007; Savvas and Ntatsi 2015). Different amounts of Si are absorbed by different species or cultivars grown at various concentrations of $\mathrm{Si}$ (Henriet et al. 2006; Savvas and Ntatsi 2015). Depending on the potato variety, the $\mathrm{Si}$ content in potato (Solanum tuberosum L.) tubers may vary from 209 to $479 \mathrm{mg} \mathrm{kg}^{-1}$ (Jitsuyama et al. 2009). The content of Si in potato leaves was studied under normal conditions with lack of drought as well as under drought-stressed conditions. In the case of normal conditions, the Si content was analyzed at the level of $0.37 \%$ d.m. (without Si fertilization) and $0.42 \%$ (after Si fertilization), whereas $0.41 \%$ d.m. and $0.47 \%$ d.m. were the contents of $\mathrm{Si}$ in potato leaves under stress conditions, respectively, for no and after Si fertilization (Crusciol et al. 2009). The silicon content was higher in corn leaves (Zea mays L.) and soybean leaves (Glycine $\max (\mathrm{L}$.) Merr.) after the application of silicon in the form of the soil fertilization (Castro and Crusiol 2015). As it was proved in a number of studies, silicon fertilization affects its higher content in different plant tissues (Savvas and Ntatsi 2015). Maize (Zea mays L.) and mallow (Malva verticillata L.) treated by nitrogen fertilization were proved to have a significantly lower content of $\mathrm{Si}$ in silage made of plants fertilized with high doses of nitrogen (Zieleniewicz and Wróbel 2018). With the increase in silicon content, the increase in $\mathrm{K}$ concentration was noticed in leaves, stems and roots and 
Table 1 The beneficial effects of using silicon

\begin{tabular}{|c|c|c|}
\hline Plant & Silicon form & Reference \\
\hline $\begin{array}{l}\text { Common } \\
\text { bean }\end{array}$ & Stabilized orthosilicic acid & Crusciol et al. (2013) \\
\hline \multirow{3}{*}{$\begin{array}{l}\text { Corn for } \\
\text { grain }\end{array}$} & Mixture of ortho- and polysilicic acid & Ambroziak (2017); Zamojska et al. (2018) \\
\hline & Stabilized orthosilicic acid & Jawahar et al. (2017) \\
\hline & Finely ground marine calcite & Prifti and Maçi (2017) \\
\hline \multirow[t]{3}{*}{ Grapes } & Finely ground marine calcite & Kara and Sabir (2010) \\
\hline & Stabilized orthosilicic acid & Bhavya et al. (2011), Ramteke et al. (2012), Laane (2017) \\
\hline & Potassium silicate & Al-Wasfy (2014) \\
\hline $\begin{array}{l}\text { Grass- } \\
\text { clover } \\
\text { sward }\end{array}$ & $\begin{array}{l}\text { Finely ground marine calcite mixture of ortho- and } \\
\text { polysilicic acid }\end{array}$ & Mastalerczuk et al. (2020) \\
\hline Hops & Finely ground marine calcite & Weihrauch and Sterler (2011) \\
\hline Meadows & Mixture of ortho- and polysilicic acid & Radkowski et al. (2017) \\
\hline \multirow{2}{*}{$\begin{array}{l}\text { Pea for } \\
\quad \text { cultivation }\end{array}$} & Potassium silicate & Rodrigues et al. (2010); \\
\hline & Mixture of ortho- and polysilicic acid & Sulewska et al. (2018) \\
\hline \multirow[t]{2}{*}{ potato } & Stabilized orthosilicic acid & $\begin{array}{l}\text { Soratto et al. (2012)b, Wróbel (2012), Pilon et al. (2013), Khan and } \\
\text { Jain (2017), Laane(2017); Trawczyński (2018) }\end{array}$ \\
\hline & Finely ground marine calcite & Trawczyński (2013) \\
\hline \multirow[t]{4}{*}{ Sugar beet } & Finely ground marine calcite & Artyszak et al. (2014), (2016) \\
\hline & $\begin{array}{l}\text { Finely ground marine calcite, mixture of ortho- and } \\
\text { polysilicic acid }\end{array}$ & Artyszak et al. (2015) \\
\hline & $\begin{array}{l}\text { Finely ground marine calcite; mixture of ortho- and } \\
\text { polysilicic acid; stabilized orthosilicic acid }\end{array}$ & Artyszak (2017) \\
\hline & Hydrated $\mathrm{SiO}_{2}$ nanoparticles & Hrivna et al. (2017); Urban and Pulrabek (2018) \\
\hline \multirow[t]{4}{*}{ Soybean } & Potassium silicate & Rodrigues et al. (2009) \\
\hline & Stabilized orthosilicic acid & Crusciol et al. (2013); \\
\hline & Mixture of ortho- and polysilicic acid & $\begin{array}{l}\text { Kalandyk and Dubert (2014); Ciecierski (2016); Shwethakumari et al. } \\
\text { (2017); }\end{array}$ \\
\hline & Mixture of ortho- and polysilicic acid & Sulewska and Ratajczak (2017) \\
\hline Sunflower & Not specified & Assis et al. (2013) \\
\hline $\begin{array}{l}\text { Timothy } \\
\text { meadow }\end{array}$ & Mixture of ortho- and polysilicic acid & Radkowski and Radkowska (2018) \\
\hline \multirow[t]{5}{*}{ Wheat } & Stabilized orthosilicic acid & $\begin{array}{l}\text { Soratto et al. (2012)a; Ratnakumar et al. (2016); Laane (2017); } \\
\text { Kowalska et al. (2020) }\end{array}$ \\
\hline & Potassium silicate & Belanger et al. (2003); Guével et al. (2007) \\
\hline & Amorphous diatomaceous earth form & Kowalska et al. (2020) \\
\hline & Finely ground marine calcite & Prifti and Maçi (2017) \\
\hline & Mixture of ortho- and polysilicic acid & Ciecierski (2016); Ambroziak (2017); Zamojska et al. (2018); \\
\hline White oat & Stabilized orthosilicic acid & Soratto et al. (2012a) \\
\hline \multirow[t]{2}{*}{ White lupin } & Mixture of ortho- and polysilicic acid & Sulewska et al. (2018); \\
\hline & Mixture of ortho- and polysilicic acid & Niewiadomska et al. (2020) \\
\hline \multirow{3}{*}{$\begin{array}{l}\text { Winter } \\
\text { oilseed } \\
\text { rape }\end{array}$} & Mixture of ortho- and polysilicic acid & Ciecierski and Kardasz (2014) \\
\hline & Finely ground marine calcite & Artyszak and Kucińska (2016) \\
\hline & Mixture of ortho- and polysilicic acid & Zamojska et al. (2018) \\
\hline
\end{tabular}

the deficiency of potassium in soybean seedlings was reduced after the addition of silicon to seedling growth medium characterized by a low potassium content (Miao et al. 2010). The foliar application of some phyto-extracts with silicon fertilizer resulted in the increase in silicon in roots and leaves of pea plants exposed to salt stress (Shahid et al. 2015). According to the literature reports, only few studies focused on the effect of the foliar application of 
silicon on its content in sugar beet plants (Artyszak et al. 2018) but also on the content of silicon depending on the use of foliar fertilizers not containing this element (Artyszak et al. 2019). On the basis of recent reports, marine calcite and a mixture of ortho- and polysilicic acid have been used so far (Artyszak et al. 2018).

The aim of the study was to assess the impact of foliar application of various forms of silicon (marine calcite, mixtures of ortho- and polysilicic acid and orthosilicic acid) on the chemical composition of sugar beet leaves in the critical phase of nutrient supply as well as sugar beet leaves and roots during harvest. The following hypothesis was proposed: foliar application of silicon significantly modifies the content of macroelements and silicon in sugar beet plants and has a beneficial effect on the course of life processes in plants subjected to stress conditions caused by water shortage.

\section{Materials and Methods}

The experiment was carried out in Sahryń $\left(50^{\circ} 41^{\prime} \mathrm{N}\right.$, $23^{\circ} 46^{\prime}$ E) in 2015-2016. The soil type was Calcic Chernozem (Aric, Siltic) (IUSS Working Group WRB 2015). The soil conditions are presented in Table 2. Years of research were characterized by adverse weather conditions for the growth and yielding of sugar beet. The amount of precipitation during the growing season (April-October) was $435 \mathrm{~mm}$ in 2015 and $420 \mathrm{~mm}$ in 2016 (Table 3). The largest rainfall deficiency occurred in June and August 2015 and in June and July, as well as in September 2016. The average daily temperature in the study period was greater than the values from the multi-year period in August and September 2015, as well as from April to September in 2016 (Artyszak 2017). Sugar beets were cultivated in the fourth rotation period: sugar beet-winter wheat-winter rape. The winter rapeseed was a forecrop for sugar beet. Rape straw yield was about $7 \mathrm{tha}^{-1}$. During the rape harvest, the straw was ground and mixed with the soil with a stubble field aggregate. In the autumn, fertilization with Polifoska 6 fertilizer (6\% $\mathrm{N}$ in ammonium form, $8.7 \%$ $\mathrm{P}$ as mono- and diammonium phosphate, $24.9 \% \mathrm{~K}$ as potassium chloride, $2.8 \% \mathrm{~S}$ as sulfate) was applied at a dose of $450 \mathrm{~kg} \mathrm{ha}^{-1}$, followed by a deep pre-winter plowing to a depth of $25 \mathrm{~cm}$. In spring, before sowing, Saletrzak Standard 27 - ammonium nitrate with the addition of dolomite flour containing calcium and magnesium $(13.5 \% \mathrm{~N}$ in the ammonium form and $13.5 \% \mathrm{~N}$ in the nitrate form, $1.4 \% \mathrm{Ca}, 2.4 \% \mathrm{Mg}$ ) was applied at a dose of $400 \mathrm{~kg} \mathrm{ha}^{-1}$. Then, the fertilizer was mixed with the soil using a soil cultivator. Total doses of nutrients were: $135 \mathrm{~kg} \mathrm{~N}, 39.2 \mathrm{~kg} \mathrm{P}, 112.1 \mathrm{~kg} \mathrm{~K}, 12.6 \mathrm{~kg} \mathrm{~S}, 9.6 \mathrm{~kg} \mathrm{Mg}$ and $5.6 \mathrm{~kg} \mathrm{Ca} \mathrm{ha}^{-1}$. In the experiment, a variety of sugar beet-Beta vulgaris (L.) ssp. vulgaris conv. crassa (Alef.) prov. altissima (Döll) Primadonna KWS-was sown. Three silicon-containing products were used in the experiment: Actisil, Herbagreen Z20 and Optysil. Actisil contains silicon $\left(6 \mathrm{~g} \mathrm{dm}^{-3} \mathrm{Si}\right)$ in the form of choline-stabilized orthosilicic acid and calcium $\left(20 \mathrm{~g} \mathrm{dm}^{-3} \mathrm{Ca}\right)$ and it is characterized by a significantly low $\mathrm{pH}(0.1)$. Herbagreen $\mathrm{Z} 20$ is a finely ground marine calcite containing silicon in a crystalline form $\left(130 \mathrm{~g} \mathrm{~kg}^{-1} \mathrm{Si}\right)$, macronutrients $\left(220 \mathrm{~g} \mathrm{~kg}^{-1} \mathrm{Ca} ; 9.6 \mathrm{~g} \mathrm{~kg}^{-1} \mathrm{Mg} ; 5 \mathrm{~g} \mathrm{~kg}^{-1} \mathrm{~K} ; 1 \mathrm{~g} \mathrm{~kg}^{-1} \mathrm{~S}\right.$; $\left.0.9 \mathrm{~g} \mathrm{~kg}^{-1} \mathrm{P}\right)$ and iron $\left(21 \mathrm{~g} \mathrm{~kg}^{-1} \mathrm{Fe}\right)$. Optysil is neutral and contains silicon in the form of a mixture of ortho- and polysilicic acid $\left(94 \mathrm{~g} \mathrm{dm}^{-3} \mathrm{Si}\right)$ and iron $\left(24 \mathrm{~g} \mathrm{dm}^{-3} \mathrm{Fe}\right)$.

Depending on the variant, each of the products was used one, two or three times (Table 4). The working fluid was prepared immediately before application. The dose of water in each spraying was $250 \mathrm{dm}^{3} \mathrm{ha}^{-1}$. Actisil and Optysil were used at a concentration of $0.2 \%$, whereas Herbagreen $\mathrm{Z} 20$ at the concentration of $0.4 \%$. The application was made with an Appollo tractor sprayer (Krukowiak).

The experiment was based on a randomized block system; however, due to the lack of significant block influence in statistical analyzes, the block effect was omitted, i.e., the analyses were performed for a completely randomized system.

The number of repetitions was 4 and the total number of plots was 40. Each plot included 6 rows. Dimensions of a single plot were the length of $16 \mathrm{~m}$ and width of $2.7 \mathrm{~m}$ $\left(43.2 \mathrm{~m}^{2}\right.$ ), of which $21.6 \mathrm{~m}^{2}$ was for harvesting (3 middle rows). After 4 weeks from the last foliar application (July 4 in 2015 and July 8 in 2016), ten leaves from the entire plot were taken from the center of the rosette.

Table 2 Characteristics of soil conditions in Sahryń 2014-2015 (0-30 cm)

\begin{tabular}{|c|c|c|c|c|c|c|c|c|c|c|c|c|}
\hline \multirow[t]{2}{*}{ Year } & \multirow[t]{2}{*}{$\mathrm{pH}_{\mathrm{KCl}}$} & \multirow[t]{2}{*}{$\mathrm{C}_{\mathrm{org}}, \mathrm{g} \mathrm{kg}^{-1}$} & \multicolumn{10}{|c|}{$\mathrm{mg} \mathrm{kg}^{-1}$ soil } \\
\hline & & & $\mathrm{N}-\mathrm{NO}_{3}$ & $\mathrm{~N}-\mathrm{NH}_{4}$ & $\mathrm{P}$ & $\mathrm{K}$ & $\mathrm{Mg}$ & B & $\mathrm{Cu}$ & $\mathrm{Fe}$ & Mn & $\mathrm{Zn}$ \\
\hline 2014 & 5.62 & 8.48 & 12.7 & 30.3 & 53.6 & 75.8 & 61.0 & 0.22 & 4.00 & 730 & 189 & 4.90 \\
\hline 2015 & 6.77 & 9.38 & 14.4 & 6.0 & 85.5 & 95.5 & 70.0 & 0.53 & 5.00 & 760 & 225 & 5.20 \\
\hline
\end{tabular}


Table 3 Weather conditions during vegetation period in Sahryń in 2015-2016

\begin{tabular}{|c|c|c|c|c|c|c|c|c|}
\hline \multirow[t]{2}{*}{ Month } & \multicolumn{3}{|c|}{ Rainfall, mm } & \multicolumn{3}{|c|}{ Average temperature, ${ }^{\circ} \mathrm{C}$} & \multicolumn{2}{|c|}{ Selyaninov's coefficient, K } \\
\hline & 2015 & 2016 & 1991-2016 & 2015 & 2016 & 2002-2016 & 2015 & 2016 \\
\hline IV & 42 & 58 & 41 & 8.1 & 10.5 & 9.0 & 1.73 & 1.84 \\
\hline $\mathrm{V}$ & 97 & 52 & 73 & 13.0 & 14.5 & 14.2 & 2.41 & 1.16 \\
\hline VI & 18 & 54 & 73 & 17.5 & 19.0 & 17.3 & 0.34 & 0.95 \\
\hline VII & 87 & 66 & 99 & 19.8 & 20.2 & 19.8 & 1.42 & 1.05 \\
\hline VIII & 3 & 52 & 62 & 20.8 & 18.9 & 18.6 & 0.05 & 0.89 \\
\hline IX & 114 & 14 & 60 & 16.1 & 15.8 & 13.6 & 2.36 & 0.30 \\
\hline$X$ & 74 & 124 & 50 & 7.2 & 6.6 & 8.0 & 3.32 & 6.06 \\
\hline$\sum$ & 435 & 420 & 458 & - & - & - & - & - \\
\hline
\end{tabular}

$\mathrm{K}=$ Monthly rainfall / $0.1 \times$ Sum of the average daily temperature

Source Own study based on data Strzyzów Sugar Factory

Table 4 Experimental variants in an experiment

\begin{tabular}{|c|c|c|c|c|}
\hline \multirow{2}{*}{$\begin{array}{l}\text { Fertilization } \\
\text { variant }\end{array}$} & \multicolumn{3}{|l|}{ Spraying date } & \multirow[t]{2}{*}{ Total dose } \\
\hline & $\begin{array}{l}6 \text { leaf stage } \\
(\mathrm{BBCH} 16)\end{array}$ & 7 days later & 14 days later & \\
\hline 0 & - & - & - & - \\
\hline 1 & $\begin{array}{l}\text { Actisil }-0.5 \mathrm{dm}^{3} \\
\mathrm{ha}^{-1}\end{array}$ & - & - & $10 \mathrm{~g} \mathrm{ha}^{-1} \mathrm{Ca}+3 \mathrm{~g} \mathrm{ha}^{-1} \mathrm{Si}+$ choline \\
\hline 2 & $\begin{array}{l}\text { Actisil }\left(0.5 \mathrm{dm}^{3}\right. \\
\left.\text { ha }^{-1}\right)\end{array}$ & $\begin{array}{l}\text { Actisil }\left(0.5 \mathrm{dm}^{3}\right. \\
\left.\mathrm{ha}^{-1}\right)\end{array}$ & - & $20 \mathrm{~g} \mathrm{ha}^{-1} \mathrm{Ca}+6 \mathrm{~g} \mathrm{ha}^{-1} \mathrm{Si}+$ choline \\
\hline 3 & $\begin{array}{l}\text { Actisil }\left(0.5 \mathrm{dm}^{3}\right. \\
\left.\mathrm{ha}^{-1}\right)\end{array}$ & $\begin{array}{l}\text { Actisil }\left(0.5 \mathrm{dm}^{3}\right. \\
\left.\mathrm{ha}^{-1}\right)\end{array}$ & $\begin{array}{l}\text { Actisil }\left(0.5 \mathrm{dm}^{3}\right. \\
\left.\text { ha }^{-1}\right)\end{array}$ & $30 \mathrm{~g} \mathrm{ha}^{-1} \mathrm{Ca}+9 \mathrm{~g} \mathrm{ha}^{-1} \mathrm{Si}+$ choline \\
\hline 4 & $\begin{array}{l}\text { Herbagreen } \mathrm{Z} 20 \\
\quad\left(1 \mathrm{~kg} \mathrm{ha}^{-1}\right)\end{array}$ & - & - & $\begin{array}{l}220 \mathrm{~g} \mathrm{ha}^{-1} \mathrm{Ca}, 130 \mathrm{~g} \mathrm{ha}^{-1} \mathrm{Si}, 21 \mathrm{~g} \mathrm{ha}^{-1} \mathrm{Fe}, 9,6 \mathrm{~g} \mathrm{ha}^{-1} \mathrm{Mg} \\
5 \mathrm{~g} \mathrm{ha}^{-1} \mathrm{~K}, 1 \mathrm{~g} \mathrm{ha}^{-1} \mathrm{~S}, 0.9 \mathrm{~g} \mathrm{ha}^{-1} \mathrm{P}\end{array}$ \\
\hline 5 & $\begin{array}{l}\text { Herbagreen } \mathrm{Z} 20 \\
\quad\left(1 \mathrm{~kg} \mathrm{ha}^{-1}\right)\end{array}$ & $\begin{array}{l}\text { Herbagreen } \mathrm{Z} 20 \\
\quad\left(1 \mathrm{~kg} \mathrm{ha}^{-1}\right)\end{array}$ & - & $\begin{array}{l}440 \mathrm{~g} \mathrm{ha}^{-1} \mathrm{Ca}, 260 \mathrm{~g} \mathrm{ha}^{-1} \mathrm{Si}, 42 \mathrm{~g} \mathrm{ha}^{-1} \mathrm{Fe}, 19.2 \mathrm{~g} \mathrm{ha}^{-1} \mathrm{Mg} \text {, } \\
10 \mathrm{~g} \mathrm{ha}^{-1} \mathrm{~K}, 2 \mathrm{~g} \mathrm{ha}^{-1} \mathrm{~S}, 1,8 \mathrm{~g} \mathrm{ha}^{-1} \mathrm{P}\end{array}$ \\
\hline 6 & $\begin{array}{l}\text { Herbagreen } \mathrm{Z} 20 \\
\quad\left(1 \mathrm{~kg} \mathrm{ha}^{-1}\right)\end{array}$ & $\begin{array}{l}\text { Herbagreen Z20 } \\
\quad\left(1 \mathrm{~kg} \mathrm{ha}^{-1}\right)\end{array}$ & $\begin{array}{l}\text { Herbagreen } \mathrm{Z} 20 \\
\quad\left(1 \mathrm{~kg} \mathrm{ha}^{-1}\right)\end{array}$ & $\begin{array}{l}660 \mathrm{~g} \mathrm{ha}^{-1} \mathrm{Ca}, 390 \mathrm{~g} \mathrm{ha}^{-1} \mathrm{Si}, 63 \mathrm{~g} \mathrm{ha}^{-1} \mathrm{Fe}, 28.8 \mathrm{~g} \mathrm{ha}^{-1} \mathrm{Mg} \text {, } \\
15 \mathrm{~g} \mathrm{ha}^{-1} \mathrm{~K}, 3 \mathrm{~g} \mathrm{ha}^{-1} \mathrm{~S}, 2,7 \mathrm{~g} \mathrm{ha}^{-1} \mathrm{P}\end{array}$ \\
\hline 7 & $\begin{array}{l}\text { Optysil }\left(0.5 \mathrm{dm}^{3}\right. \\
\left.\mathrm{ha}^{-1}\right)\end{array}$ & - & - & $47 \mathrm{~g} \mathrm{ha}^{-1} \mathrm{Si}+12 \mathrm{~g} \mathrm{ha}^{-1} \mathrm{Fe}$ \\
\hline 8 & $\begin{array}{l}\text { Optysil }\left(0.5 \mathrm{dm}^{3}\right. \\
\left.\mathrm{ha}^{-1}\right)\end{array}$ & $\begin{array}{l}\text { Optysil }\left(0.5 \mathrm{dm}^{3}\right. \\
\left.\mathrm{ha}^{-1}\right)\end{array}$ & - & $94 \mathrm{~g} \mathrm{ha}^{-1} \mathrm{Si}+24 \mathrm{~g} \mathrm{ha}^{-1} \mathrm{Fe}$ \\
\hline 9 & $\begin{array}{l}\text { Optysil }\left(0.5 \mathrm{dm}^{3}\right. \\
\left.\mathrm{ha}^{-1}\right)\end{array}$ & $\begin{array}{l}\text { Optysil }\left(0.5 \mathrm{dm}^{3}\right. \\
\left.\mathrm{ha}^{-1}\right)\end{array}$ & $\begin{array}{l}\text { Optysil }\left(0.5 \mathrm{dm}^{3}\right. \\
\left.\mathrm{ha}^{-1}\right)\end{array}$ & $141 \mathrm{~g} \mathrm{ha}^{-1} \mathrm{Si}+36 \mathrm{~g} \mathrm{ha}^{-1} \mathrm{Fe}$ \\
\hline
\end{tabular}

\section{Dry Matter Content}

During harvest, representative samples of leaves and roots were taken from each plot to determine the dry matter content (PN-R-04013 1988). The dry matter content was determined by the oven-drying method in the laboratory of the Agronomy Department, Warsaw University of Life Sciences. According to this methodology, the samples of roots fresh mass $(100 \mathrm{~g})$ and leaves blades $(100 \mathrm{~g})$ were collected and dried in an oven-dryer at a temperature of $75{ }^{\circ} \mathrm{C}$ to a constant weight.

\section{The Content of N, P, K, Ca and Mg}

The contents of nutrients, such as N, P, K, Ca and Mg were determined in an air-dry plant material using a closed-tube sulfuric acid/hydrogen peroxide digestion method at the Warsaw-Wesoła Regional Agrochemical Station (Poland). The nutrient content was determined by the following 
methods: nitrogen, by direct potentiometric titration with sodium hypobromite (Kjeldahl); phosphorus, by the spectrophotometric method with a solution of nitric acid, ammonium metavanadate and ammonium molybdate, at a wavelength of $470 \mathrm{~nm}$ and potassium calcium and magnesium by flame atomic absorption spectrometry (FAAS) at a wavelength of $766.5 ; 422.7$ and $285.2 \mathrm{~nm}$, respectively (PB No 59 2015; PB No 20 2011a; PB No 21 2011b; PB No 22 2011c; PB No 23 2011d).

\section{The Content of Silicon}

The determination of silicon content in leaves and roots of sugar beet was determined using the WDXRF (Wavelength Dispersive X-Ray florescence) technique. Samples were analyzed using a commercial WDXRF spectrometer Thermo Scientific ${ }^{\mathrm{TM}}$ ARL $^{\mathrm{TM}}$ PERFORM'X WDXRF $^{\mathrm{TM}}$ (Thermo Fisher Scientific, Madison, WI, USA), equipped with a Rh lamp with a maximum excitation power of $4.2 \mathrm{~kW}$. All measurements were performed under high vacuum to avoid signal loss caused by air absorption. After drying the material was next ground, homogenized and sieved through a mesh width of $75 \mu \mathrm{m}$ before pelletizing. This step is essential for obtaining homogeneity in three dimensions throughout the excitation volume of the sample, which is called the matrix effect of the sample.

The premix powder (approx. $2 \mathrm{~g}$, accurately weighed; $\pm 0.0001 \mathrm{~g}$ ) was then taken and pressed into smooth pellet in aluminum cups on binder, using a 15 ton hydraulic press. Thin-walled aluminum cups (Spec-caps) were added for extra stability and to facilitate the labeling and handling of the samples once pressed. All accessories were delivered by Fluxana. The pellet had intermediate thickness and a disc shape with $32 \mathrm{~mm}$ diameter. All WDXRF analysis were performed on three different pellets. However, the time between pelletization and analysis should be as short as possible in order to avoid deformation of the flat surfaces of the pellets. Due to unavailability of reference samples for the specified matrix, it was necessary to develop a set of calibration and validation standards for the collected analytical material. The reference values of silicon content in the standards were determined using a validated internal procedure with the UniQuant fundamental parameters method. A total of 15 beet leaves samples were used to prepare the method calibration (calibration kit). The validation kit contained 1 sample of the reference material. The method was evaluated using the reference material obtained through participation in interlaboratory tests (IPE 2015.1). Accuracy and precision of the results were verified by the analysis of the reference material. The results showed good accuracy with relative errors $\leq 3 \%$ for the $\mathrm{Si}$ and good precision of relative standard deviations (RSDs) $\leq 5 \%$.

\section{The Content of Sucrose, Alpha-Amino Nitrogen, Na and $K$}

During harvest, the plants in the middle 3 rows were topped manually and the leaves were weighed. Then, the roots were counted, dug and weighed. During harvest, representative root samples were taken from each plot to determine their technological quality (sugar, alpha-amino nitrogen, $\mathrm{K}$ and Na content) (PN-R-74458 1999).

Sugar, alpha-amino nitrogen, $\mathrm{Na}$, and $\mathrm{K}$ contents were determined using the automatic beet analysis system "Venema" by Kutno Sugar Beet Breeding Station Ltd. in Straszków, Poland. Root yields and their technological quality were reported already in the literature (Artyszak 2017). Pure sugar yield was calculated from the following formulas (Buchholz et al. 1995):

$$
\begin{aligned}
\text { Pure sugar yield }\left(\mathrm{t} \mathrm{ha}^{-1}\right) & =\text { Root yield }\left(\mathrm{t} \mathrm{ha}^{-1}\right) \\
& \times[\text { sugar content }(\%) \\
& - \text { sugar efficiency loss }(\%)]
\end{aligned}
$$

Sugar efficiency loss $(\%)=$ Standard loss of molasses $(\%)$

$$
+0.6(\%)
$$

Standard loss of molasses (\%)

$$
=0.012 \times(\mathrm{K}+\mathrm{Na})+0.024(\alpha-\text { amino } \mathrm{N})+0.48
$$

where $\mathrm{K}, \mathrm{Na}$, and alpha-amino $\mathrm{N}$ content are provided as mmol kg${ }^{-1}$ of the pulp.

The yields of leaf and root with regard to dry matter (d.m.) were calculated as the products of the yield and the d.m. content. The uptake of N, P, K, Mg, Ca, and Si was calculated on the basis of their content in plants and the dry matter yield. The experimental data were statistically analyzed by one-way analysis of variance, and the mean values were compared using the least significant difference, with the level of significance of $\alpha=0.05$. Statistical analyses were performed with SAS 9.1 software (Cary, USA) by using the GLM (General Linear Model) procedure. The evaluation of the correlation between the measured traits was calculated using simple Pearson's correlation coefficients. The significance of correlations was assessed at $p$ $\leq 0.05$ and $p \leq 0.01$. Relationships between the pure sugar yield and the macronutrients and Si content in leaves and roots were evaluated using multiple regression with backward selection of variables. 
Table 5 Effect of foliar fertilization with silicon on the chemical content of sugar beet leaves in July (mean values from 2015 to 2016)

\begin{tabular}{|c|c|c|c|c|c|c|}
\hline \multirow[t]{2}{*}{ Fertilization variant } & \multicolumn{6}{|c|}{$\mathrm{g} \mathrm{kg}^{-1}$ dry matter (d.m.) } \\
\hline & $\mathrm{Si}$ & $\mathrm{N}$ & $\mathrm{P}$ & K & $\mathrm{Mg}$ & $\mathrm{Ca}$ \\
\hline 0 & $2.32^{\mathrm{a} 1}$ & $28.50^{\text {cde }}$ & $2.43^{\mathrm{b}}$ & $39.45^{\mathrm{abc}}$ & $3.58^{\mathrm{a}}$ & $14.63^{\mathrm{a}}$ \\
\hline 1 & $1.46^{\mathrm{a}}$ & $21.68^{\mathrm{a}}$ & $2.15^{\mathrm{a}}$ & $39.30^{\mathrm{abc}}$ & $4.43^{\mathrm{b}}$ & $16.28^{\mathrm{abc}}$ \\
\hline 2 & $1.39^{\mathrm{a}}$ & $28.30^{\text {cde }}$ & $2.23^{\mathrm{ab}}$ & $38.35^{\mathrm{ab}}$ & $4.60^{\mathrm{b}}$ & $16.83^{\text {bcd }}$ \\
\hline 3 & $1.49^{\mathrm{a}}$ & $28.03^{\text {cde }}$ & $2.28^{\mathrm{ab}}$ & $43.60^{\mathrm{cd}}$ & $4.33^{\mathrm{ab}}$ & $18.28^{\mathrm{d}}$ \\
\hline 4 & $2.17^{\mathrm{a}}$ & $26.70^{\mathrm{cd}}$ & $2.48^{\mathrm{b}}$ & $43.40^{\mathrm{cd}}$ & $4.85^{\mathrm{b}}$ & $15.58^{\mathrm{ab}}$ \\
\hline 5 & $1.24^{\mathrm{a}}$ & $29.75^{\mathrm{e}}$ & $2.53^{\mathrm{b}}$ & $42.30^{\mathrm{bcd}}$ & $6.15^{\mathrm{c}}$ & $16.95^{\text {bcd }}$ \\
\hline 6 & $2.36^{\mathrm{a}}$ & $28.93^{\text {cde }}$ & $2.50^{\mathrm{b}}$ & $37.10^{\mathrm{a}}$ & $6.63^{\mathrm{c}}$ & $17.38^{\mathrm{cd}}$ \\
\hline 7 & $2.13^{\mathrm{a}}$ & $29.30^{\mathrm{de}}$ & $2.35^{\mathrm{ab}}$ & $37.75^{\mathrm{a}}$ & $5.93^{c}$ & $17.10^{\text {bcd }}$ \\
\hline 8 & $1.60^{\mathrm{a}}$ & $25.00^{\mathrm{b}}$ & $2.13^{\mathrm{a}}$ & $46.40^{\mathrm{d}}$ & $5.88^{\mathrm{c}}$ & $16.50^{\mathrm{bc}}$ \\
\hline 9 & $1.41^{\mathrm{a}}$ & $26.93^{\mathrm{bcd}}$ & $2.30^{\mathrm{ab}}$ & $38.60^{\mathrm{ab}}$ & $4.98^{\mathrm{b}}$ & $15.50^{\mathrm{ab}}$ \\
\hline
\end{tabular}

${ }^{1}$ Different letters in columns indicate significant differences between mean values for variants at the 0.05 probability level

\section{Results}

Depending on the application variant, the silicon content in leaves collected at the beginning of July ranged from 1.24 to $2.36 \mathrm{~g} \mathrm{~kg}^{-1} \mathrm{~d} . \mathrm{m}$. and was similar as in the control combination $-22.36 \mathrm{~g} \mathrm{~kg}^{-1} \mathrm{~d} . \mathrm{m}$. (Table 5). In the vast majority of experimental combinations, no significant effect of the foliar application on the content of nitrogen, phosphorus and potassium in the leaves was found. However, a significant increase in the content of magnesium and calcium was observed.

The silicon content in the leaves at harvest was higher than in the leaves collected in July (Table 6). In the variants with foliar application of silicon it was 3.85-5.34 $\mathrm{g} \mathrm{kg}^{-1} \mathrm{~d} . \mathrm{m}$. and was comparable to the control-4.60 $\mathrm{g} \mathrm{kg}^{-1} \mathrm{~d} . \mathrm{m}$. The applied combinations of foliar application had no significant effect on the content of macronutrients in almost all combinations in a relation to the control object.

The content of silicon in the roots during harvest on the objects with foliar feed was 2.91-3.84 $\mathrm{g} \mathrm{kg}^{-1} \mathrm{~d}$.m. and was similar to the control variant, except for variant No. 3 , in the case of which it was significantly lower. The effect of the applied variants of foliar application in the nitrogen content in the roots was ambiguous; four variants were analyzed with no effect; in three, it significantly decreased, and in two other, the increase in nitrogen content was noticed. In the case of potassium, foliar application of silicon in two variants significantly increased the content of this element compared to control. The calcium content in roots of any combination was not significantly different in a comparison with the control. The tendency to accumulate higher amounts of phosphorus and magnesium in the roots was observed on almost on studied objects with foliar application of silicon products compared to the control.
The uptake of silicon accumulated in the leaves was 16.0-25.5 kg ha ${ }^{-1}$ (Table 7). The foliar application of silicon favored the uptake of larger amounts of silicon, and a significant difference was demonstrated in a relation to the control object in variants 2, 3 and 9. The uptake of nitrogen, phosphorus, potassium, magnesium and calcium in leaves was usually higher than in the control variant.

The uptake of silicon in the roots was $48,3-66.0 \mathrm{~kg} \mathrm{ha}^{-1}$ $\mathrm{Si}$. Its uptake and accumulation in the roots did not differ significantly depending on the experimental combination. The significantly higher nitrogen uptake was found in variants 4, 5 and 9, whereas potassium in variants 1 and 6 but also calcium in variants 2 and 3 compared to the control object. The uptake of phosphorus and magnesium in the roots was much higher after foliar application of silicon. The total silicon uptake by plants (in leaves and roots) amounted to a total of $67.8-90.4 \mathrm{~kg} \mathrm{ha}^{-1} \mathrm{Si}$ and on all combinations with foliar application it was similar to that of the control. The uptake of macronutrients usually increased under the influence of foliar silicon.

Silicon was accumulated mainly in the roots, from 20.9 to $31.5 \%$ of the intake of this component $(27.3 \%$ on average) in the leaves.

The variability of the silicon content in leaves was greater at the measurement made in July than $(\mathrm{CV}=$ $82.0 \%$ ) during the harvest $(58.2 \%$ ) (Table 8$)$. In the case of macronutrients, the coefficient of variation was the highest for magnesium in both measurement dates $(\mathrm{CV}=$ 31.7 and $21.0 \%$, respectively). The variability of the content of silicon and macronutrients in the roots at harvest was greater than in the leaves.

The variability of silicon uptake by plants in leaves was lower $(\mathrm{CV}=48.4 \%)$ than in roots $(\mathrm{CV}=58.4 \%)$ (Table 9). The value of the coefficient of variation (CV) for the uptake of macronutrients located in leaves was similar 
Table 6 Effect of foliar fertilization with silicon on the chemical content of sugar beet leaves and roots during harvest (mean values from 2015 to 2016)

\begin{tabular}{|c|c|c|c|c|c|c|}
\hline \multirow[t]{2}{*}{ Fertilization Variant } & \multicolumn{6}{|c|}{$\mathrm{g} \mathrm{kg}^{-1}$ d.m. } \\
\hline & $\mathrm{Si}$ & $\mathrm{N}$ & $\mathrm{P}$ & $\mathrm{K}$ & $\mathrm{Mg}$ & $\mathrm{Ca}$ \\
\hline \multicolumn{7}{|l|}{ Leaves } \\
\hline 0 & $4.60^{\mathrm{abc} 1}$ & $22.75^{\mathrm{b}}$ & $1.50^{\mathrm{ab}}$ & $35.65^{\mathrm{abc}}$ & $8.10^{\mathrm{ab}}$ & $20.00^{\mathrm{ab}}$ \\
\hline 1 & $3.85^{\mathrm{a}}$ & $22.13^{\mathrm{b}}$ & $1.58^{\mathrm{ab}}$ & $37.85^{\mathrm{bc}}$ & $9.20^{\mathrm{bcd}}$ & $18.83^{\mathrm{ab}}$ \\
\hline 2 & $4.88^{\mathrm{abc}}$ & $21.70^{\mathrm{ab}}$ & $1.55^{\mathrm{ab}}$ & $36.60^{\mathrm{abc}}$ & $9.60^{\mathrm{cd}}$ & $23.55^{\mathrm{c}}$ \\
\hline 3 & $4.47^{\mathrm{abc}}$ & $19.75 \mathrm{a}$ & $1.63^{\mathrm{b}}$ & $37.80^{\mathrm{bc}}$ & $7.70^{\mathrm{a}}$ & $19.03^{\mathrm{ab}}$ \\
\hline 4 & $5.34^{\mathrm{c}}$ & $22.20^{\mathrm{b}}$ & $1.60^{\mathrm{ab}}$ & $32.50^{\mathrm{a}}$ & $8.43^{\mathrm{abc}}$ & $20.83^{\mathrm{b}}$ \\
\hline 5 & $4.74^{\mathrm{abc}}$ & $22.48^{\mathrm{b}}$ & $1.63^{\mathrm{b}}$ & $33.70^{\mathrm{ab}}$ & $9.13^{\mathrm{bcd}}$ & $20.18^{\mathrm{ab}}$ \\
\hline 6 & $3.91^{\mathrm{ab}}$ & $21.93^{\mathrm{b}}$ & $1.45^{\mathrm{a}}$ & $32.20^{\mathrm{a}}$ & $10.23^{\mathrm{d}}$ & $24.30^{\mathrm{c}}$ \\
\hline 7 & $4.60^{\mathrm{abc}}$ & $21.95^{\mathrm{b}}$ & $1.63^{\mathrm{b}}$ & $38.90^{c}$ & $8.10^{\mathrm{ab}}$ & $18.30^{\mathrm{a}}$ \\
\hline 8 & $4.19^{\mathrm{ab}}$ & $23.08^{\mathrm{b}}$ & $1.63^{\mathrm{b}}$ & $37.30^{\mathrm{bc}}$ & $8.60^{\mathrm{abc}}$ & $18.28^{\mathrm{a}}$ \\
\hline 9 & $4.91^{\mathrm{bc}}$ & $21.15^{\mathrm{ab}}$ & $1.63^{\mathrm{b}}$ & $36.60^{\mathrm{abc}}$ & $9.15^{\mathrm{bcd}}$ & $18.75^{\mathrm{ab}}$ \\
\hline \multicolumn{7}{|l|}{ Roots } \\
\hline 0 & $4.20^{\mathrm{b}}$ & $7.25^{\mathrm{b}}$ & $0.70^{\mathrm{a}}$ & $3.20^{\mathrm{a}}$ & $0.85^{\mathrm{ab}}$ & $2.78^{\mathrm{abcd}}$ \\
\hline 1 & $3.45^{\mathrm{ab}}$ & $7.80^{\mathrm{bc}}$ & $0.95^{\mathrm{cd}}$ & $4.90^{\mathrm{c}}$ & $0.98^{\text {bcd }}$ & $2.95^{\mathrm{bcd}}$ \\
\hline 2 & $3.66^{\mathrm{ab}}$ & $6.30^{\mathrm{a}}$ & $0.83^{\mathrm{bc}}$ & $3.40^{\mathrm{ab}}$ & $0.80^{\mathrm{a}}$ & $3.35^{\mathrm{d}}$ \\
\hline 3 & $2.91^{\mathrm{a}}$ & $6.15^{\mathrm{a}}$ & $0.80^{\mathrm{ab}}$ & $3.10^{\mathrm{a}}$ & $0.85^{\mathrm{ab}}$ & $3.08^{\mathrm{cd}}$ \\
\hline 4 & $3.10^{\mathrm{ab}}$ & $9.48^{\mathrm{d}}$ & $0.83^{\mathrm{abc}}$ & $3.80^{\mathrm{ab}}$ & $1.03^{\mathrm{d}}$ & $2.65^{\mathrm{abc}}$ \\
\hline 5 & $3.47^{\mathrm{ab}}$ & $8.38^{\mathrm{c}}$ & $0.83^{\mathrm{abc}}$ & $3.30^{\mathrm{a}}$ & $1.00^{\mathrm{cd}}$ & $2.80^{\mathrm{abcd}}$ \\
\hline 6 & $3.53^{\mathrm{ab}}$ & $6.15^{\mathrm{a}}$ & $0.88^{\mathrm{bc}}$ & $4.20^{\mathrm{bc}}$ & $0.88^{\mathrm{abc}}$ & $2.20^{\mathrm{a}}$ \\
\hline 7 & $3.36^{\mathrm{ab}}$ & $7.95^{\mathrm{bc}}$ & $0.83^{\mathrm{abc}}$ & $3.15^{\mathrm{a}}$ & $1.03^{\mathrm{d}}$ & $3.13^{\mathrm{cd}}$ \\
\hline 8 & $3.40^{\mathrm{ab}}$ & $7.80^{\mathrm{bc}}$ & $0.85^{\mathrm{bc}}$ & $3.50^{\mathrm{ab}}$ & $1.05^{\mathrm{d}}$ & $2.78^{\mathrm{abcd}}$ \\
\hline 9 & $3.84^{\mathrm{ab}}$ & $7.80^{\mathrm{bc}}$ & $1.03^{\mathrm{d}}$ & $3.60^{\mathrm{ab}}$ & $1.05^{\mathrm{d}}$ & $2.38^{\mathrm{ab}}$ \\
\hline
\end{tabular}

${ }^{1}$ Different letters in columns indicate significant differences between mean values for variants at the 0.05 probability level

(29.8-32.3\%). On the other hand, in roots, the $\mathrm{CV}$ value was the highest for calcium and potassium $(45.5-45.9 \%)$.

The pure sugar yield (average from 2015 to 2016) was in the following variation: $0-9.93 \mathrm{t} \mathrm{ha}^{-1}, 1-10.41 \mathrm{t} \mathrm{ha}^{-1}$, $2-12.07 \mathrm{t} \mathrm{ha}^{-1}, 3-12.13 \mathrm{t} \mathrm{ha}^{-1}, 4-10.63 \mathrm{t} \mathrm{ha}^{-1}, 5-10.65 \mathrm{t}$ $\mathrm{ha}^{-1}, 6-10.78 \mathrm{t} \mathrm{ha}^{-1}, 7-10.52 \mathrm{t} \mathrm{ha}^{-1}, 8-10.55 \mathrm{t} \mathrm{ha}^{-1}$ and 9-11.33 t ha-1 (Artyszak 2017).

The content of silicon and magnesium in leaves in July was negatively correlated, and the content of phosphorus and calcium was positively correlated with the technological yield of sugar (Table 10). On the other hand, in the case of the content of silicon, nitrogen, potassium and magnesium in the leaves during harvest, their significant negative relationship with the technological yield was found. The technological yield of sugar was significantly positively correlated with the content of phosphorus, potassium and calcium in the roots, and negatively with the content of silicon, nitrogen and magnesium. The uptake of macronutrients, both in leaves, roots and in total, was significantly positively related to the pure sugar yield. A similar relationship was found in the case of silicon uptake and the pure sugar yield, but it was significantly negative.

\section{Discussion}

The available literature lacks the results of the studies on the content of silicon in leaves of sugar beet in the critical phase of nutrient supply. Therefore, the presented research results are of great value. The nitrogen content of fully developed leaves of sugar beet at the turn of June and July should be $40-60 \mathrm{~g} \mathrm{~kg}^{-1} \mathrm{~N}$, phosphorus $3.5-6.0 \mathrm{~g} \mathrm{~kg}^{-1} \mathrm{P}$, potassium $35-70 \mathrm{~g} \mathrm{~kg}^{-1} \mathrm{~K}$, magnesium $3.0-7.0 \mathrm{~g} \mathrm{~kg}^{-1}$ $\mathrm{Mg}$ and calcium 7.0-20.0 $\mathrm{g} \mathrm{kg}^{-1} \mathrm{Ca}$. The $\mathrm{N} / \mathrm{K}$ ratio should be below 1.0 (Bergmann 1992). In own research, the desired value was obtained in each of the tested variants. The plants, however, were malnourished with phosphorus.

The potassium and nitrogen content in the leaves in the critical phase of the nutrient supply is influenced, among others, by potassium fertilization. In studies by Musolf et al. (2004), the potassium content in plant leaves, determined at the beginning of July, was $68 \mathrm{~g} \mathrm{~kg}^{-1} \mathrm{~K}$ on the object fertilized with potassium and $52 \mathrm{~g} \mathrm{~kg}^{-1} \mathrm{~K}$ on the object not fertilized with this element, and the nitrogen content was 40.3 and $31.0 \mathrm{~g} \mathrm{~kg}^{-1} \mathrm{~N}$, respectively. 
Table 7 Nutrient uptake by sugar beet plants (means from 2015-2016)

\begin{tabular}{|c|c|c|c|c|c|c|}
\hline Fertilization & $\mathrm{Si}$ & $\mathrm{N}$ & $\mathrm{P}$ & $\mathrm{K}$ & $\mathrm{Mg}$ & $\mathrm{Ca}$ \\
\hline Variant & $\mathrm{kg} \mathrm{ha}^{-1}$ & & & & & \\
\hline \multicolumn{7}{|l|}{ Leaves } \\
\hline 0 & $15.98^{\mathrm{a} 1}$ & $95.38^{\mathrm{a}}$ & $6.21^{\mathrm{a}}$ & $135.86^{\mathrm{a}}$ & $34.59^{\mathrm{a}}$ & $84.70^{\mathrm{a}}$ \\
\hline 1 & $18.24^{\mathrm{ab}}$ & $118.10^{\mathrm{bc}}$ & $8.60^{\mathrm{bcd}}$ & $193.41^{\mathrm{bc}}$ & $48.55^{\mathrm{c}}$ & $101.32^{\mathrm{ab}}$ \\
\hline 2 & $24.45^{\mathrm{bc}}$ & $112.55^{\mathrm{abc}}$ & $8.17^{\mathrm{bcd}}$ & $194.65^{\mathrm{bc}}$ & $51.09^{c}$ & $125.37^{\mathrm{d}}$ \\
\hline 3 & $23.53^{\mathrm{bc}}$ & $105.23^{\mathrm{abc}}$ & $8.89^{\mathrm{cd}}$ & $208.13^{c}$ & $41.99^{\mathrm{abc}}$ & $104.36^{\mathrm{bc}}$ \\
\hline 4 & $19.55^{\mathrm{abc}}$ & $98.43^{\mathrm{ab}}$ & $7.28^{\mathrm{ab}}$ & $141.10^{\mathrm{a}}$ & $37.28^{\mathrm{ab}}$ & $99.54^{\mathrm{ab}}$ \\
\hline 5 & $21.13^{\mathrm{abc}}$ & $109.07^{\mathrm{abc}}$ & $8.07^{\mathrm{bcd}}$ & $166.15^{\mathrm{ab}}$ & $45.12^{\mathrm{bc}}$ & $102.63^{\mathrm{ab}}$ \\
\hline 6 & $18.75^{\mathrm{abc}}$ & $110.99^{\mathrm{abc}}$ & $7.40^{\mathrm{abc}}$ & $166.37^{\mathrm{ab}}$ & $50.41^{\mathrm{c}}$ & $123.03^{\mathrm{cd}}$ \\
\hline 7 & $18.70^{\mathrm{ab}}$ & $102.34^{\mathrm{abc}}$ & $7.90^{\mathrm{bcd}}$ & $188.67^{\mathrm{bc}}$ & $36.98^{\mathrm{ab}}$ & $87.41^{\mathrm{ab}}$ \\
\hline 8 & $18.57^{\mathrm{ab}}$ & $121.57^{\mathrm{c}}$ & $8.52^{\text {bcd }}$ & $206.13^{\mathrm{bc}}$ & $46.07^{\mathrm{bc}}$ & $99.85^{\mathrm{ab}}$ \\
\hline 9 & $25.50^{\mathrm{c}}$ & $117.67^{\mathrm{bc}}$ & $9.15^{\mathrm{d}}$ & $200.25^{\mathrm{bc}}$ & $50.39^{c}$ & $104.87^{\mathrm{bc}}$ \\
\hline \multicolumn{7}{|l|}{ Roots } \\
\hline 0 & $60.45^{\mathrm{a}}$ & $107.78^{\mathrm{ab}}$ & $10.41^{\mathrm{a}}$ & $48.74^{\mathrm{a}}$ & $12.46^{\mathrm{a}}$ & $41.63^{\mathrm{a}}$ \\
\hline 1 & $50.34^{\mathrm{a}}$ & $120.74^{\mathrm{bc}}$ & $15.26^{\mathrm{bc}}$ & $79.74^{\mathrm{c}}$ & $15.16^{\mathrm{abc}}$ & $47.42^{\mathrm{ab}}$ \\
\hline 2 & $65.98^{\mathrm{a}}$ & $115.17^{\mathrm{abc}}$ & $15.30^{\mathrm{bc}}$ & $62.80^{\mathrm{abc}}$ & $14.70^{\mathrm{abc}}$ & $61.58^{\mathrm{c}}$ \\
\hline 3 & $51.12^{\mathrm{a}}$ & $112.98^{\mathrm{abc}}$ & $14.68^{\mathrm{bc}}$ & $57.92^{\mathrm{ab}}$ & $15.41^{\mathrm{abc}}$ & $58.40^{\mathrm{bc}}$ \\
\hline 4 & $48.26^{\mathrm{a}}$ & $158.18^{\mathrm{d}}$ & $13.66^{\mathrm{ab}}$ & $63.55^{\mathrm{abc}}$ & $16.38^{\mathrm{bc}}$ & $45.89^{\mathrm{ab}}$ \\
\hline 5 & $50.41^{\mathrm{a}}$ & $127.96^{\mathrm{c}}$ & $13.36^{\mathrm{ab}}$ & $55.31^{\mathrm{a}}$ & $15.65^{\mathrm{bc}}$ & $47.76^{\mathrm{ab}}$ \\
\hline 6 & $55.59^{\mathrm{a}}$ & $98.82^{\mathrm{a}}$ & $15.20^{\mathrm{bc}}$ & $73.11^{\mathrm{bc}}$ & $14.28^{\mathrm{ab}}$ & $37.72^{\mathrm{a}}$ \\
\hline 7 & $49.54^{\mathrm{a}}$ & $125.97^{\mathrm{bc}}$ & $13.51^{\mathrm{ab}}$ & $53.17^{\mathrm{a}}$ & $16.38^{\mathrm{bc}}$ & $50.00^{\mathrm{ab}}$ \\
\hline 8 & $52.54^{\mathrm{a}}$ & $126.34^{\mathrm{bc}}$ & $13.92^{\mathrm{b}}$ & $58.60^{\mathrm{ab}}$ & $17.01^{\mathrm{bc}}$ & $45.77^{\mathrm{ab}}$ \\
\hline 9 & $60.70^{\mathrm{a}}$ & $129.41^{\mathrm{c}}$ & $17.33^{\mathrm{c}}$ & $60.70^{\mathrm{ab}}$ & $17.42^{\mathrm{c}}$ & $40.34^{\mathrm{a}}$ \\
\hline \multicolumn{7}{|c|}{ Leaves + roots } \\
\hline 0 & $76.44^{\mathrm{ab}}$ & $203.16^{\mathrm{a}}$ & $16.63^{\mathrm{a}}$ & $184.61^{\mathrm{a}}$ & $47.06^{\mathrm{a}}$ & $126.33^{\mathrm{a}}$ \\
\hline 1 & $68.58^{\mathrm{a}}$ & $238.84^{\text {bcd }}$ & $23.86^{\mathrm{bc}}$ & $273.15^{\mathrm{d}}$ & $63.70^{\mathrm{bc}}$ & $148.74^{\mathrm{ab}}$ \\
\hline 2 & $90.44^{\mathrm{b}}$ & $227.72^{\mathrm{abcd}}$ & $23.46^{\mathrm{bc}}$ & $257.44^{\mathrm{cd}}$ & $65.79^{\mathrm{c}}$ & $186.95^{\mathrm{c}}$ \\
\hline 3 & $74.64^{\mathrm{ab}}$ & $218.21^{\mathrm{bc}}$ & $23.56^{\mathrm{bc}}$ & $266.06^{\mathrm{d}}$ & $57.40^{\mathrm{abc}}$ & $162.76^{\mathrm{bc}}$ \\
\hline 4 & $67.80^{\mathrm{a}}$ & $256.60^{\mathrm{d}}$ & $20.94^{\mathrm{ab}}$ & $204.64^{\mathrm{ab}}$ & $53.66^{\mathrm{ab}}$ & $145.43^{\mathrm{ab}}$ \\
\hline 5 & $71.54^{\mathrm{ab}}$ & $237.03^{\mathrm{bcd}}$ & $21.43^{\mathrm{b}}$ & $221.46^{\mathrm{abc}}$ & $60.77^{\mathrm{bc}}$ & $150.38^{\mathrm{ab}}$ \\
\hline 6 & $74.34^{\mathrm{ab}}$ & $209.81^{\mathrm{ab}}$ & $22.60^{\mathrm{c}}$ & $239.49^{\mathrm{bcd}}$ & $64.70^{\mathrm{c}}$ & $160.76^{\mathrm{b}}$ \\
\hline 7 & $68.25^{\mathrm{a}}$ & $228.31^{\mathrm{abcd}}$ & $21.41^{\mathrm{b}}$ & $241.83^{\mathrm{bcd}}$ & $53.36^{\mathrm{ab}}$ & $137.41^{\mathrm{ab}}$ \\
\hline 8 & $71.11^{\mathrm{ab}}$ & $247.91^{\mathrm{cd}}$ & $22.44^{\mathrm{bc}}$ & $264.73^{\mathrm{cd}}$ & $63.08^{\mathrm{bc}}$ & $145.63^{\mathrm{ab}}$ \\
\hline 9 & $86.20^{\mathrm{ab}}$ & $247.08^{\mathrm{cd}}$ & $26.48^{\mathrm{c}}$ & $260.95^{\mathrm{cd}}$ & $67.81^{\mathrm{c}}$ & $145.22^{\mathrm{ab}}$ \\
\hline
\end{tabular}

${ }^{1}$ Different letters in columns indicate significant differences between mean values for variants at the 0.05 probability level

On the basis of present studies, it was concluded that the content of silicon in leaves and roots during harvest was several times higher than in the previous researches (Artyszak et al. 2018). Such difference may be explained by different methodology of silicon determination (Kraska and Breitenbeck 2010) as the researches were conducted in the same localization but different period (Artyszak et al. 2018, 2019).

In our research, foliar application of silicon did not significantly differentiate the silicon content in leaves during harvest. It is consistent with the results of the previous studies on the use of foliar application of marine calcite and a mixture of ortho- and polysilicic acid (Artyszak et al. 2018), as well as fertilizers containing macroand microelements without silicon in sugar beet (Artyszak et al. 2019). Spraying with Actisil in the cultivation of tomatoes grown on mineral wool and under stress conditions caused by the presence of manganese in the substrate increased the nitrogen, magnesium and sodium content in the leaves and nitrogen and sodium in the fruit. At the same time, it lowered the magnesium content in the fruit compared to the control variant (Kleiber et al. 2015b). The foliar application of Actisil led to an increase in the silicon content in the leaves of Gazania rigens (L.) Gaertn, and the 
Table 8 Variability parameters of the nutrient content in sugar beet leaves and roots in 2015 and 2016

\begin{tabular}{|c|c|c|c|c|}
\hline Element & Mean & Range & SD & Coefficient of variation, $\%$ \\
\hline \multicolumn{5}{|c|}{ Content of elements in dry matter $\left(\mathrm{g} \mathrm{kg}^{-1}\right)$, leaves (July) } \\
\hline $\mathrm{Si}$ & 1,76 & $0.44-8.21$ & 1.46 & 82.0 \\
\hline $\mathrm{N}$ & 27.3 & $18.9-34.4$ & 3.58 & 13.1 \\
\hline $\mathrm{P}$ & 2.34 & $1.70-3.40$ & 0.45 & 19.3 \\
\hline K & 40.6 & $29.2-53.2$ & 5.41 & 13.3 \\
\hline $\mathrm{Mg}$ & 5.13 & $2.30-10.6$ & 1.63 & 31.7 \\
\hline $\mathrm{Ca}$ & 16.50 & $11.20-21.8$ & 2.31 & 14.0 \\
\hline \multicolumn{5}{|c|}{ Content of elements in dry matter ( $\left.g \mathrm{~kg}^{-1}\right)$, leaves (harvest) } \\
\hline $\mathrm{Si}$ & 4.55 & $1.45-10.2$ & 2.65 & 58.2 \\
\hline $\mathrm{N}$ & 21.9 & $11.2-26.6$ & 3.27 & 14.9 \\
\hline $\mathrm{P}$ & 1.58 & $1.30-2.00$ & 0.16 & 10.4 \\
\hline $\mathrm{K}$ & 35.9 & $20.4-51.2$ & 6.87 & 19.1 \\
\hline $\mathrm{Mg}$ & 8.82 & $5.40-15.4$ & 1.85 & 21.0 \\
\hline $\mathrm{Ca}$ & 20.2 & $15.5-32.9$ & 3.19 & 15.8 \\
\hline \multicolumn{5}{|c|}{ Content of elements in dry matter $\left(g \mathrm{~kg}^{-1}\right)$, roots (harvest) } \\
\hline $\mathrm{Si}$ & 3.49 & $0.50-10.5$ & 2.22 & 63.4 \\
\hline $\mathrm{N}$ & 7.51 & $4.50-11.2$ & 1.62 & 21.6 \\
\hline $\mathrm{P}$ & 0.85 & $0.60-1.40$ & 0.20 & 22.9 \\
\hline K & 3.62 & $1.60-8.00$ & 1.32 & 36.4 \\
\hline $\mathrm{Mg}$ & 0.95 & $0.50-1.40$ & 0.20 & 20.5 \\
\hline $\mathrm{Ca}$ & 2.81 & $1.20-5.80$ & 1.02 & 36.3 \\
\hline
\end{tabular}

Table 9 Variability parameters of the nutrient uptake in sugar beet leaves and roots in 2015 and 2016

\begin{tabular}{|c|c|c|c|c|}
\hline Element & Mean & Range & $\mathrm{SD}$ & Coefficient of variation, $\%$ \\
\hline \multicolumn{5}{|c|}{ Leaves $\left(k g h a^{-1}\right)$} \\
\hline $\mathrm{Si}$ & 20.4 & $8.33-55.8$ & 9.90 & 48.4 \\
\hline $\mathrm{N}$ & 109.1 & $56.4-186.1$ & 28.1 & 25.8 \\
\hline $\mathrm{P}$ & 8.02 & $3.90-13.5$ & 2.39 & 29.8 \\
\hline $\mathrm{K}$ & 180 & $79.6-315$ & 55.3 & 30.8 \\
\hline $\mathrm{Mg}$ & 44.2 & $14.4-73.5$ & 13.2 & 29.8 \\
\hline $\mathrm{Ca}$ & 103 & $43.6-172$ & 33.4 & 32.3 \\
\hline \multicolumn{5}{|c|}{ Roots $\left(k g h a^{-1}\right)$} \\
\hline $\mathrm{Si}$ & 54.5 & $8.86-144$ & 31.8 & 58.4 \\
\hline $\mathrm{N}$ & 122 & $70.6-225$ & 27.6 & 22.6 \\
\hline $\mathrm{P}$ & 14.3 & $6.32-29.9$ & 4.83 & 33.9 \\
\hline $\mathrm{K}$ & 61.4 & $20.0-155$ & 28.2 & 45.9 \\
\hline $\mathrm{Mg}$ & 15.5 & $8.85-23.6$ & 3.31 & 21.4 \\
\hline $\mathrm{Ca}$ & 47.7 & $13.9-114$ & 21.7 & 45.5 \\
\hline \multicolumn{5}{|c|}{ Leaves + roots $\left(\mathrm{kg} \mathrm{ha}^{-1}\right)$} \\
\hline $\mathrm{Si}$ & 74.9 & $22.8-174$ & 39.5 & 52.7 \\
\hline $\mathrm{N}$ & 231 & $149-364$ & 44.1 & 19.1 \\
\hline $\mathrm{P}$ & 22.3 & $11.2-38.2$ & 6.76 & 30.3 \\
\hline $\mathrm{K}$ & 241 & $101-408$ & 71.6 & 29.6 \\
\hline $\mathrm{Mg}$ & 59.7 & $28.6-88.5$ & 13.8 & 23.1 \\
\hline $\mathrm{Ca}$ & 151 & $59.4-254$ & 49.5 & 32.8 \\
\hline
\end{tabular}


Table 10 Correlation coefficients of the pure sugar yield and the chemical content of sugar beet plants in 2015-2016 $(n=80)$

\begin{tabular}{|c|c|c|}
\hline Content/uptake; part of a plant & Element & Pure sugar yield, $\mathrm{t} \mathrm{ha}^{-1}$ \\
\hline \multirow[t]{6}{*}{ The content in leaves (July) } & $\mathrm{Si}$ & $-0.433^{* *}$ \\
\hline & $\mathrm{N}$ & -0.172 \\
\hline & $\mathrm{P}$ & $0.516 * *$ \\
\hline & $\mathrm{K}$ & -0.213 \\
\hline & $\mathrm{Mg}$ & $-0.488 * *$ \\
\hline & $\mathrm{Ca}$ & $0.318 * *$ \\
\hline \multirow[t]{6}{*}{ The content in leaves (harvest) } & $\mathrm{Si}$ & $-0.642 * *$ \\
\hline & $\mathrm{N}$ & $-0.538 * *$ \\
\hline & $\mathrm{P}$ & -0.083 \\
\hline & $\mathrm{K}$ & $-0.341 * *$ \\
\hline & $\mathrm{Mg}$ & $-0.335^{* *}$ \\
\hline & $\mathrm{Ca}$ & 0.070 \\
\hline \multirow[t]{6}{*}{ The content in roots (harvest) } & $\mathrm{Si}$ & $-0.644 * *$ \\
\hline & $\mathrm{N}$ & $-0.420 * *$ \\
\hline & $\mathrm{P}$ & $0.454 * *$ \\
\hline & $\mathrm{K}$ & $0.534 * *$ \\
\hline & $\mathrm{Mg}$ & $-0.455^{* *}$ \\
\hline & $\mathrm{Ca}$ & $0.522 * *$ \\
\hline \multirow[t]{6}{*}{ Uptake in leaves } & $\mathrm{Si}$ & $-0.250 *$ \\
\hline & $\mathrm{N}$ & $0.650 * *$ \\
\hline & $\mathrm{P}$ & $0.788 * *$ \\
\hline & $\mathrm{K}$ & $0.589 * *$ \\
\hline & $\mathrm{Mg}$ & $0.567 * *$ \\
\hline & $\mathrm{Ca}$ & $0.743 * *$ \\
\hline \multirow[t]{6}{*}{ Uptake in roots } & $\mathrm{Si}$ & $-0.410 * *$ \\
\hline & $\mathrm{N}$ & $0.302 * *$ \\
\hline & $\mathrm{P}$ & $0.756 * *$ \\
\hline & $\mathrm{K}$ & $0.726 * *$ \\
\hline & $\mathrm{Mg}$ & $0.317 * *$ \\
\hline & $\mathrm{Ca}$ & $0.731 * *$ \\
\hline \multirow[t]{6}{*}{ Uptake in leaves and roots } & $\mathrm{Si}$ & $-0.394 * *$ \\
\hline & $\mathrm{N}$ & $0.604 * *$ \\
\hline & $\mathrm{P}$ & $0.819 * *$ \\
\hline & $\mathrm{K}$ & $0.741 * *$ \\
\hline & $\mathrm{Mg}$ & $0.616^{* *}$ \\
\hline & $\mathrm{Ca}$ & $0.821 * *$ \\
\hline
\end{tabular}

**significant correlation at $p \leq 0.01$; * significant correlation at $p \leq 0.05$

lack of reaction in Verbena hybrid Voss and Salvia farinacea Benth (Dębicz et al. 2016). The addition of calcium $\left(\mathrm{Ca}_{2} \mathrm{SiO}_{3}\right)$ and ammonium $\left(\left(\mathrm{NH}_{4}\right)_{2} \mathrm{SiO}_{3}\right)$ silicates to the peat substrate increased the content of silicon in cucumber leaves and fruits (Górecki and Danielski-Busch 2009). The leaves of the silicon root-fed cucumber were characterized by significantly lower calcium and higher silicon content than in the control plants. The fruits of the cucumber fed to the root with silicon contained more dry matter, silicon and less zinc and copper than the fruits of control plants (Jarosz 2013). Tomato fruits grown on sand contained more dry matter, total sugars and potassium, and significantly more silicon compared to plants grown on mineral wool. At the same time, tomato leaves fertilized with a silicon-enriched medium contained more silicon and less manganese and zinc compared to the control plants (Jarosz 2014).

In the studies on the influence of soil cultivation on the chemical composition of sugar beet leaves, assessed in the 6-7 leaf stage (BBCH 16/17), the content of $\mathrm{N}$ was $38.4-48.7 \mathrm{~g} \mathrm{~kg}^{-1}, \mathrm{P}-2.68-4.75 \mathrm{~g} \mathrm{~kg}^{-1}, \mathrm{~K}-25.2-47.8 \mathrm{~g} \mathrm{~kg}^{-1}$, $\mathrm{Mg}-6.88-15.1 \mathrm{~g} \mathrm{~kg}^{-1}$, whereas $\mathrm{Ca}-5.36-11.1 \mathrm{~g} \mathrm{~kg}^{-1}$ (Gaj et al. 2015).

In our research, the applied combinations of foliar application did not have a significant effect on the content of macronutrients in most of combinations in a relation to the control object. The application of silicon did not significantly modify the content of mineral elements $(\mathrm{P}, \mathrm{K}$, $\mathrm{Mg}$ and $\mathrm{Ca}$ ) and the dry weight of leaves Gazania rigens (L.) Gaertn,, Salvia farinacea Benth and Verbena hybrid Voss. (Dębicz et al. 2016). Soil application of calcium silicate increased the content of silicon, phosphorus, calcium and copper, and lowered the amount of nitrogen, potassium, manganese and zinc in rice leaves (Fallah 2016). The silicon-fed lettuce contained significantly more phosphorus and potassium as well as less manganese compared to the control plants in which this element was not applied (Jarosz 2015). The use of Actisil fertilization by fertigation in the cultivation of lettuce on mineral wool with a high content of manganese in the medium significantly influenced the content of macronutrients in the above-ground parts of plants by reducing the nitrogen content and increasing the content of phosphorus, potassium, calcium and magnesium compared to the control. In the case of micronutrients, silicon significantly decreased the content of zinc and iron, with no significant effect on the content of manganese, copper and sodium (Kleiber 2014). Silicon nutrition of lettuce in hydroponic cultivation subjected to stress caused by manganese did not change the manganese content in the leaves, but caused a significant increase in nitrogen, phosphorus, sodium, iron and silicon concentrations, while reducing the zinc and copper content (Kleiber et al. 2015a).

In the studies on the effect of soil cultivation on the chemical composition of sugar beet plants in the end phase of the inter-row cover phase (BBCH 39/40), the $\mathrm{N}$ content in leaves was $21.7-41.8 \mathrm{~g} \mathrm{~kg}^{-1}$, whereas $\mathrm{P}-2.04-3.15 \mathrm{~g} \mathrm{~kg}^{-1}$, $\mathrm{K}-35.8-53.6 \mathrm{~g} \mathrm{~kg}^{-1}, \quad \mathrm{Mg}-3.27-11.6 \mathrm{~g} \mathrm{~kg}^{-1}$, and $\mathrm{Ca}-$ $5.08-13.8 \mathrm{~g} \mathrm{~kg}^{-1}$ (Gaj et al. 2015).

The effect of the foliar application of silicon-containing fertilizers on sward nutrient content was also studied (Mastalerczuk et al. 2020). The content of potassium, 
phosphorus and sodium was increased when Herbagreen (multicomponent) was applied in both years of research. In a comparison with Optysil, significantly stronger effect was observed in moist year (2016), followed by no influence in 2017.

In the presented studies, the foliar application of silicon had no significant effect on the content of silicon in sugar beet roots. Similar results were obtained in previous studies (Artyszak et al. 2018). On the other hand, foliar application of macro- and micronutrient fertilizers without silicon most often reduced the content of this element in the roots (Artyszak et al. 2019).

The uptake of silicon in leaves and roots in our own research was much higher than in the previous studies (Artyszak et al. 2018, 2019). These differences may be explained by a different method of determining the content of this element in plant material.

The foliar application of silicon favored the uptake of greater amounts of this element in the leaves compared to the control variant. In the previous studies, no significance of such an impact was found (Artyszak et al. 2018, 2019).

In our own experiment, foliar application of silicon did not have a significant effect on the uptake of silicon stored in the roots, which confirms the results of previous studies (Artyszak et al. 2018). On the other hand, foliar application of macro- and microelements led to a reduction in silicon uptake in the roots compared to the object without foliar feeding (Artyszak et al. 2019).

The total silicon uptake by plants was much higher than in the previous studies (Artyszak et al. 2018, 2019), which results from a different methodology for determining the silicon content. The amount of total silicon uptake on all combinations with foliar application was similar to the control. Similar results were obtained earlier (Artyszak et al. 2018). On the other hand, the use of silicon-free foliar fertilizers reduced the uptake of silicon in the roots (Artyszak et al. 2019). Moreover, about 30\% of the silicon taken up by plants was stored in leaves, and about $70 \%$ in the roots. Similar results were obtained earlier (Artyszak et al. 2019).

The Si uptake of nearly 50 plants grown hydroponically showed a general pattern of Si deposition along the leaf margins and in the leaf trichomes. Minimal Si was found in the roots and stems (Makabe et al. 2009). The salinityinduced reduction in $\mathrm{K}$ content was partially ameliorated by $\mathrm{Si}$ application, particularly in the roots of the common bean (Phaseolus vulgaris L.) (Zuccarini 2008). In the cultivation of four grasses, the correlations between $\mathrm{Si}$ and $\mathrm{P}$ uptake was observed (Eneji et al. 2008). Similar relationships were observed in a relation to microelements (Hernandez-Apaola 2014). In the cultivation of wheat the $P$ uptake in both hydroponics and the soil was improved even at low $\mathrm{Si}$ concentrations via the activation of H-ATPase
(Mali and Aery 2008a). The effect of various concentrations of $\mathrm{Si}$ as sodium metasilicate on nodule growth and mineral nutrition of Rhizobium sp. U 15-inoculated cowpea (Vigna unguiculata (L.) Walp.) plants grown in pots was studied. Lower addition of Si significantly increased nitrogen, phosphorus, and calcium concentrations. Plant Si concentrations increased together with an increase in soilapplied Si (Mali and Aery 2008b).

The variability of silicon content in leaves and roots during harvest and silicon uptake by plants in leaves and roots was similar to previous studies on foliar application of marine calcite and a mixture of ortho- and polysilicic acid (Artyszak et al. 2018) and lower than in experiments with foliar silicon-free fertilizers (Artyszak et al. 2019). On the other hand, the variability of the total silicon uptake by plants (in leaves + in roots) was lower than in the studies with the foliar application of silicon (Artyszak et al. 2018).

The content of silicon and magnesium in leaves in July were negatively and phosphorus and calcium positively correlated with the pure sugar yield. A positive relationship between potassium and calcium content in leaves determined during this period and the sugar yield was found by Wojciechowski et al. (2002a).

The experiment showed a negative significant relationship between the silicon content in leaves and roots during harvest and the pure sugar yield. Earlier studies revealed a significant positive relationship between these features (Artyszak et al. 2018) or no relationship (Artyszak et al. 2019).

The pure sugar yield was significantly positively correlated with the content of phosphorus, potassium and calcium in the roots, and negatively with the content of silicon, nitrogen and magnesium. The uptake of macronutrients, both in leaves, roots and in total, was significantly positively related to the pure sugar yield. In the studies by Wojciechowski et al. (2002b), the sugar yield significantly depended on the amount of potassium taken up only in the year when soil drought occurred.

A similar relationship was found in the case of taking up silicon and the pure sugar yield, but it was significantly negative. In research on potatoes, Si content was not correlated with some yield features (LeRiche et al. 2009).

\section{Conclusions}

(1) Silicon foliar application has a significant impact on the content of magnesium and calcium in sugar beet leaves determined in the critical phase of nutrient supply.

(2) Sugar beet absorbs approx. $75 \mathrm{~kg}$ of $\mathrm{Si} \mathrm{ha}^{-1}$, which is almost 3.5 times more than $\mathrm{P}$ and $20 \%$ more than $\mathrm{Mg}$, which proves that it is an important element for sugar 
beet. About $70 \%$ of the silicon taken up is stored in the roots and $30 \%$ in the leaves.

(3) The pure sugar yield is most favorably influenced by two- and threefold foliar application of the product containing silicon in the form of orthosilicic acid stabilized with choline, and a threefold mixture of ortho- and polysilicic acid.

(4) The increase in the pure sugar yield is not the result of a change in the chemical composition of sugar beet plants, but their more efficient functioning after foliar application of silicon under stress conditions caused by water shortage.

Acknowledgements The authors would like to express their sincere gratitude to Intermag Ltd., NaturalCrop Ltd. and Yara Poland Ltd. for their assistance in conducting the experiments.

\section{Data Availability None.}

\section{Compliance with Ethical Standards}

Conflict of interest The authors declare that they have no conflict of interest.

Open Access This article is licensed under a Creative Commons Attribution 4.0 International License, which permits use, sharing, adaptation, distribution and reproduction in any medium or format, as long as you give appropriate credit to the original author(s) and the source, provide a link to the Creative Commons licence, and indicate if changes were made. The images or other third party material in this article are included in the article's Creative Commons licence, unless indicated otherwise in a credit line to the material. If material is not included in the article's Creative Commons licence and your intended use is not permitted by statutory regulation or exceeds the permitted use, you will need to obtain permission directly from the copyright holder. To view a copy of this licence, visit http://creativecommons.org/licenses/by/4.0/.

\section{References}

Al-Wasfy, M.M.M. 2014. The synergistic effects of using silicon with some vitamins on growth and fruiting of flame seedless grapevines. Stem Cell 5: 8-13.

Ambroziak, J. 2017. Foliar application of $\mathrm{pH}$ neutral product and its effect on abiotic stress mitigation in field crops. In Proceedings of 7th international conference on silicon in agriculture, 105, Bengaluru, India.

Artyszak, A. 2017. Possibilities of using silicon for foliar fertilization of sugar beet. Poland: Wieś Jutra Warsaw.

Artyszak, A. 2018. Effect of silicon fertilization on crop yield quantity and quality-a literature review in Europe. Plants 7: 54. https://doi.org/10.3390/plants7030054.

Artyszak, A., D. Gozdowski, and K. Kucińska. 2014. The effect of foliar fertilization with marine calcite in sugar beet. Plant Soil and Environment 60: 413-417.

Artyszak, A., D. Gozdowski, and K. Kucińska. 2015. The effect of silicon foliar fertilization in sugar beet - Beta vulgaris (L.) ssp. vulgaris conv. crassa (Alef.) prov. altissima (Döll). Turkish Journal of Field Crops 20: 115-119.
Artyszak, A., D. Gozdowski, and K. Kucińska. 2016. The effect of calcium and silicon foliar fertilization in sugar beet. Sugar Tech 18: $109-114$.

Artyszak, A., D. Gozdowski, and K. Kucińska. 2018. Vliv hnojení křemíkem a vápníkem či jen křemíkem na chemické složení cukrové řepy. Listy Cukrovarnické a Řepařské 134: 19-25.

Artyszak, A., D. Gozdowski, and K. Kucińska. 2019. Impact of foliar fertilization on the content of silicon and macronutrients in sugar beet. Plants 8: 136. https://doi.org/10.3390/plants8050136.

Artyszak, A. and K. Kucińska. 2016. Silicon nutrition and crop improvement: Recent advances and future perspective. In Silicon in plants, ed. Tripathi, D.K., Singh, V.P., Ahmad, P., Chauhan, D.K., Prasad, S.M., 297-319, London, UK; New York, NY, USA: CRC Press Taylor \& Francis Group Boca Raton.

Assis, F.A., J.C. Moraes, A.M. Auad, and M. Coelho. 2013. The effects of foliar spray application of silicon on plant damage levels and components of larval biology of the pest butterfly Chlosyne lacinia saundersii (Nymphalidae). International Journal of Pest Management 59: 128-134.

Belanger, R.R., N. Benhamou, and J.G. Menzies. 2003. Cytological evidence of an active role of silicon in wheat resistance to powdery mildew (Blumeria graminis f. sp. tritici). Phytopathology 93: 402-412. https://doi.org/10.1094/PHYTO.2003.93.4.402.

Bhavya, H.K., V.V. Nache Gowda, S. Jaganath, K.N. Sreenivas, and N.B. Prakash. 2011. Effect of foliar silicic acid and boron acid in Bangalore blue grapes. In Proceedings of the 5th international conference on silicon in argriculture, 7-8, China, Beijing.

Bergmann, W. 1992. Nutritional disorders of plants, 117-131. Jena, Stuttgart, New Jork: Gustav. Fischer Verlag.

Buchholz, K., B. Märländer, H. Puke, H. Glattkowski, and K. Thielecke. 1995. Neubewertung des technischen Wertes von Zuckerrben. Zuckerindustrie 120: 113-121.

Castro, G.S.A., and C.A.C. Crusciol. 2015. Effects of surface application of dolomitic limestone and calcium-magnesium silicate on soybean and maize in rotation with green manure in a tropical region. Bragantia 74: 311-321.

Ciecierski, W. 2016. Effect of silicon on biotic and abiotic stress mitigation in horticultural and field crops. In Proceedings of the international symposium "Mikroelementy $w$ rolnictwie $i$ środowisku", 25, Kudowa-Zdrój, Poland.

Ciecierski, W. and H. Kardasz. 2014. Impact of silicon based fertilizer Optysil on abiotic stress reduction and yield improvement in field crops. In Proceedings of 6th conference on silicon in agriculture. 54-55, Stockholm, Sweden.

Crusciol, C.A.C., A.L. Pulz, L.B. Lemos, R.P. Soratto, and G.P.P. Lima. 2009. Effects of silicon and drought stress on tuber yield and leaf biochemical characteristics in potato. Crop Science 49: 949-954.

Crusciol, C.A.C., R.P. Soratto, G.S.A. Castro, C.H.M. Costa, and J.F. Neto. 2013. Foliar application of stabilized silicic acid on soybean, common bean, and peanut. Revista Ciência Agronômica 44: 404-410.

Currie, H., and C. Perry. 2007. Silica in plants: biological, biochemical and chemical studies. Annals of Botany 100: 1383-1389.

Dębicz, R., A. Pawlikowska, K. Wróblewska, and P. Bąbelewski. 2016. Influence of foliar treatment with silicon contained in the Actisil Hydro Plus preparation on the growth, flowering and chemical composition of Gazania rigens (L.) Gaertn., Salvia farinacea Benth and Verbena hybrida Voss. Journal of Elementology 21: 681-692. https://doi.org/10.5601/jelem.2015.20.2.909.

Eneji, A.E., I. Shinobu, M. Satoru, L. Jing, H. Taiichiro, A. Ping, and W. Tsuji. 2008. Growth and nutrient use in four grasses under drought stress as mediated by silicon fertilizers. Journal of Plant Nutrition 31: 355-365.

Fallah, A. 2016. Silicon nutrition and rice crop improvement in Iran: recent advances and future perspectives. In Silicon in plants, ed. 
Tripathi, D.K., Singh, V.P., Ahmad, P., Chauhan, D.K., Prasad, S.M., 343-354, London, UK; New York, NY, USA: CRC Press Taylor \& Francis Group Boca Raton.

Gaj, R., A. Budka, A. Niewiadomska, J. Przybył, and N. Mioduszewska. 2015. Effect of different tillage methods on the nutritional status, yield and quality of sugar beets. Journal of $\begin{array}{llll}\text { Elementology } & 20 & \text { (3): }\end{array}$ https://doi.org/10.5601/jelem.2015.20.1.772.

Górecki, R.S., and W. Danielski-Busch. 2009. Effect of silicate fertilizers on yielding of greenhouse cucumber (Cucumis sativus L.) in container cultivation. Journal of Elementology 14: 71-78.

Guével, M.H., J.G. Menzies, and E.E. Bélanger. 2007. Effect of root and foliar applications of soluble silicon on powdery mildew control and growth of wheat plants. European Journal of Plant Pathology 119: 429-436.

Henriet, C., X. Draye, I. Oppitz, R. Swennen, and B. Delvaux. 2006. Effects, distribution and uptake of silicon in banana (Musa spp.) under controlled conditions. Plant and Soil 287: 359-374.

Hernandez-Apaola, L. 2014. Can silicon partially alleviate micronutrient deficiency in plants? a review. Planta 240: 447-458. https://doi.org/10.1007/s00425-014-2119-x.

Hřivna, L., J. Hernandez Kong, L. Machálková, I. Burešová, E. Sapáková, J. Kučerová, and V. Šottníková. 2017. Vliv mimokořenové výživy draslíkem a křemíkem na výnos a kvalitu cukrovky $\mathrm{v}$ nestandardních povětrnostních podmínkách roku 2014 a 2015. Listy Cukrovarnické a Repařské 133: 182-187.

IUSS Working Group WRB. 2015. World Reference Base for Soil Resources 2014. international soil classification system for naming soils and creating legends for soil maps. Update 2015; World Soil Resources Raport 106, Rome, Italy: FAO.

Jarosz, Z. 2013. The effect of silicon application and type of substrate on yield and chemical composition of leaves and fruit of cucumber. Journal of Elementology 3: 403-414.

Jarosz, Z. 2014. The effect of silicon application and type of medium on yielding and chemical composition of tomato. Acta Scientiarum Polonorum Hortorum Cultus 13: 171-183.

Jarosz, Z. 2015. Wpływ zróżnicowanych dawek krzemu i manganu na wielkość oraz skład chemiczny główek sałaty. Nauka Przyroda Technologie 9 (1): 1. https://doi.org/10.17306/j.npt.2015.1.1.

Jawahar, S., C. Kalaiyarasan, M.V. Sriramachandrasekharan, N. Jain, and M. Naveenkumar. 2017. Effect of orthosilicic acid formula on growth and yield of maize in different soils. In Proceedings of the 7 th international conference on silicon in agriculture, p. 132, Bengaluru, India.

Jitsuyama, Y., T. Akihiko, M. Chiharu, I. Kazuto, and S. Ichikawa. 2009. Endogenous components and tissue cell morphological traits of fresh potato tubers affect the flavour of steamed tubers. American Journal of Potato Research 86: 430-441.

Kalandyk, A., P. Waligórski, and F. Dubert. 2014. Zastosowanie biostymulatorów w łagodzeniu skutków suszy i innych stresów środowiskowych u soi zwyczajnej (Glycine $\max$ L. Merr.). Episteme Czasopismo Naukowo-Kulturalne 22 (3): 267-274.

Kara, Z. and A. Sabir. 2010. Effects of herbagreen application on vegetative developments of some grapevine rootstocks during nursery propagation in glasshouse. In Proceedings of the 2nd international symposium on sustainable development, 127-132, Sarajevo, Bosnia and Herzegovina.

Khan, M.A., Goyal, V. and N. Jain. 2017. Impact of ortho silicic acid formulation on yield and disease incidence of potatoes. In Proceedings of the 7th international conference on silicon in agriculture, 137, Bengaluru, India.

Kleiber, T. 2014. The effect of choline-stabilized orthosilicic acid application under Mn excessive nutrition on yielding of hydroponically grown head lettuce (Lactuca sativa L.). Aparatura Badawcza i Dydaktyczna 3: 219-226.
Kleiber, T., W. Krzesiński, K. Przygocka-Cyna, and T. Spiżewski. 2015a. The response of hydroponically grown lettuce under Mn stress to differentiated application of silica sol. Journal of Elementology 20:

609-619. https://doi.org/10.5601/jelem.2015.20.1.806.

Kleiber, T., M. Bosiacki, and W. Breś. 2015b. The effect of cholinestabilized orthosilic acid application on tomato grown under increasing Mn stress. Journal of Elementology 20: 897-910. https://doi.org/10.5601/jelem.2015.20.1.820.

Kowalska, J., J. Tyburski, J. Kowalska, and J. Krzymińska. 2020. Effect of different forms of silicon on growth of spring wheat cultivated in organic farming system. Silicon. https://doi.org/10.1007/s12633-020-00414-4.

Kraska, J.E., and G. Breitenbeck. 2010. Simple, robust method for quantifying silicon in plant tissue. Communications Soil Science and Plant Analysis 41: 2075-2085.

Laane, H.M. 2017. The effects of the application of foliar sprays with stabilized silicic acid: An overview of the results from 2003-2014. Silicon 9: 803-807.

Laane, H.M. 2018. The effects of foliar sprays with different silicon compounds. Plants 7: 45. https://doi.org/10.3390/plants7020045.

LeRiche, E.L., G. Wang-Pruski, and V.D. Zheljazkov. 2009. Distribution of elements in potato (Solanum tuberosum L.) tubers and their relationship to after-cooking darkening. HortScience 44 (7): 1866-1873. https://doi.org/10.21273/hortsci.44.7.1866.

Makabe, S., K. Kakuda, Y. Sasaki, T. Ando, H. Fujii, and H. Adno. 2009. Relationship between mineral composition or soil texture and available silicon in alluvial paddy soils on the Shounai plain. Japanese Journal of Soil Science and Plant Nutrition 55: 300-308.

Mali, M., and N.C. Aery. 2008a. Influence of silicon on growth, relative water contents and uptake of silicon, calcium and potassium in wheat grown in nutrient solution. Journal of Plant Nutrition 31: 1867-1876.

Mali, M., and N.C. Aery. 2008b. Silicon effects on nodule growth, dry-matter production, and mineral nutrition of cowpea (Vigna unguiculata). Journal of Plant Nutrition and Soil Science 171: $835-840$

Mastalerczuk, G., B. Borawska-Jarmułowicz, P. Dąbrowski, E. Szara, A. Perzanowska, and B. Wróbel. 2020. Can the cpplication the silicon improve the productivity and nutritional value of grassclover sward in conditions of rainfall shortage in organic management? Agronomy 10: 1007. https://doi.org/10.3390/agronomy10071007.

Miao, B.H., X.G. Han, and W.H. Zhang. 2010. The ameliorative effect of silicon on soybean seedlings grown in potassium deficient medium. Annals of Botany 105: 967-973. https://doi.org/10.1093/aob/mcq063.

Musolf, R., W. Grzebisz, W. Szczepaniak, and M. Chojnacka. 2004. Effect of potassium fertilization under diversified water conditions on yield and quality of sugar beets (Beta vulgaris L.) Part III. Plant nutrition with potassium and nitrogen. Biuletyn Instytutu Hodowli i Aklimatyzacji Roslin 234: 123-128.

Niewiadomska, A., H. Sulewska, A. Wolna-Maruwka, K. Ratajczak, Z. Waraczewska, and A. Budka. 2020. The Influence of biostimulants and foliar fertilizers on yield, plant features, and the level of soil biochemical activity in white lupine (Lupinus albus L.) cultivation. Agronomy 10: 150. https://doi.org/10.3390/agronomy10010150.

OSChR. 2015. Procedura badawcza OSChR w Warszawie nr PB 59 ed. 2 .

OSChR. 2011a. Procedura badawcza OSChR w Warszawie nr PB 20 ed. 6.

OSChR. 2011b. Procedura badawcza OSChR w Warszawie nr PB 21 ed. 6 . 
OSChR 2011c. Procedura badawcza OSChR w Warszawie nr PB 22 ed. 5 .

OSChR. 2011d. Procedura badawcza OSChR w Warszawie nr PB 23 ed. 6 .

Pilon, C., R.P. Soratto, and L.A. Moreno. 2013. Effects of soil and foliar application of soluble silicon on mineral nutrition, gas exchange, and growth of potato plants. Crop Science 53: 1605-1614. https://doi.org/10.2135/cropsci2012.10.0580.

Polska Norma PN-R-04013. 1988. Analiza chemiczno-rolnicza roślin - oznaczanie powietrznie suchej i suchej masy.

Polska Norma PN-R-74458. 1999. Korzenie buraka cukrowego.

Prifti, D., and A. Maçi. 2017. Effect of herbagreen nano-particles on biochemical and technological parameters of cereals (wheat and corn). European Scientific Journal 13: 72-83. https://doi.org/10.19044/esj.2017.v13n6p72.

Radkowski, A., and I. Radkowska. 2018. Effects of silicate fertilizer on seed yield in timothy-grass (Phleum pratense L.). Ecological Chemistry and Engineering $S$ 25: 169-180. https://doi.org/10.1515/Eces-2018-0012.

Radkowski, A., E. Sosin-Bzducha, and I. Radkowska. 2017. Effects of silicon foliar fertilization of meadow plants on nutritional value of silage fed to dairy cows. Journal of Elementology 22 (4): 1311-1322. https://doi.org/10.5601/jelem.2017.22.1.1331.

Ramteke, S.D., R.J. Kor, M.A. Bhanga, A.P. Khot, N.A. Zende, S.S. Datir, and K.D. Ahire. 2012. Physiological studies on effects of Silixol on quality and yield in Thompson seedless grapes. Annals of Plant Physiology 26 (2): 47-51.

Ratnakumar, P., P.P. Deokate, J. Rane, N. Jain, V. Kumar, D. Vanden Berghe, and P.S. Minhas. 2016. Effect of ortho-silicic acid exogenous application on wheat (Triticum aestivum L.) under drought. Journal of Functional and Environmental Botany 6 (1): 34-42. https://doi.org/10.5958/2231-1750.2016.00006.8.

Rodrigues, F.A., H.S.S. Duarte, G.P. Domiciano, C.A. Souza, G.H. Korndörfer, and L. Zambolim. 2009. Foliar application of potassium silicate reduces the intensity of soybean rust. Australasian Plant Pathology 38 (4): 366-372. https://doi.org/10.1071/AP09010.

Rodrigues, F.A., H.S.S. Duarte, D.C. Rezende, J.A. Wordell Filho, G.H. Korndörfer, and L. Zambolim. 2010. Foliar spray of potassium silicate on the control of angular leaf spot on beans. Journal of Plant Nutrition 33 (14): 2082-2093. https://doi.org/10.1080/01904167.2010.519082.

Savvas, D., and G. Ntatsi. 2015. Biostimulant activity of silicon in horticulture. Scientia Horticulturae 196: 66-81.

Shahid, M.A., R.M. Balal, M.A. Pervez, T. Abbas, M.A. Aqeel, M.M. Javaid, and F. Garcia-Sanchez. 2015. Foliar spray of phytoextracts supplemented with silicon: an efficacious strategy to alleviate the salinity-induced deleterious effects in pea (Pisum sativum L.). Turkish Journal of Botany 39 (3): 408-419. https://doi.org/10.3906/bot-1406-84.

Shwethakumari, U., Prakash, N.B., Gowda, J. and M. Chandrappa. 2017. Effect of foliar application of silicic acid on growth, yield and quality of soybean [Glycine max. (L)]. In Proceedings of the 7th international conference on silicon in agriculture, 146, Bengaluru, India.

Soratto, R.P., C.A.C. Crusciol, G.S.A. Castro, C.H.M. Costa, and J.F. Neto. 2012a. Leaf applications of silicic acid to white oat and wheat. Revista Brasileira de Ciência do Solo 36 (5): 1538-1544. https://doi.org/10.1590/S0100-06832012000500018.
Soratto, R.P., A.N. Fernandes, C.A.C. Crusciol, and G.D. de SouzaSchlick. 2012b. Produtividade, qualidade de tubérculos e incidência de doenças em batata, influenciados pela aplicação foliar de silício. Pesquisa Agropecuária Brasileira 47 (7): $1000-1006$.

Sulewska, H., and K. Ratajczak. 2017. Chemical composition of selected preparations supporting plant development and evaluation of their activity in soybean cultivation. Przemyst Chemiczny 96: 1352-1355.

Sulewska, H., K. Ratajczak, A. Niewiadomska, W. Koziara, K. Panasiewicz, and A. Faligowska. 2018. Titanium, silicon, boron, zinc and molybdenum-containing formulations in the white lupine and pea cultivation. Przemyst Chemiczny 97: 1182-1185. https://doi.org/10.15199/62.2018.7.30.

Trawczyński, C. 2013. Wpływ dolistnego nawożenia preparatem Herbagreen na plonowanie ziemniaków. Ziemniak Polski 2: 29-33.

Trawczyński, C. 2018. The effect of foliar preparation with silicon on the yield and quality of potato tubers in compared to selected biostimulators. Fragmenta Agronomica 35 (4): 113-122. https://doi.org/10.26374/fa.2018.35.47.

Urban, J., and J. Pulkrabek. 2018. Navyšeni vynosu a jakosti cukrove řepy pomoci listove vyživy a biologicky aktivnich latek. Listy Cukrovarnické a Repařské 134: 188-194.

Weihrauch, F., Schwarz, J. and A. Sterler. 2011. Downy mildew control in organic hops: how much copper is actually needed? In Proceedings of the scientific commission CIH-IHB-IHGC, 75-78, Lublin, Poland.

Wojciechowski, A., W. Szczepaniak, and W. Grzebisz. 2002a. Effect of potassium fertilization on yields and technological quality of sugar beet Part II. An assessment of plants nutritional status. Biuletyn Instytutu Hodowli i Aklimatyzacji Roslin 222: 65-70.

Wojciechowski, A., W. Szczepaniak, and W. Grzebisz. 2002b. Effect of potassium fertilization on yields and technological quality of sugar beet Part III. Potassium uptake. Biuletyn Instytutu Hodowli i Aklimatyzacji Roslin 222: 71-77.

Wróbel, S. 2012. Wpływ nawożenia ziemniaka odmiany Jelly dolistnymi preparatami yaravita ziemniak oraz actisil na plon i cechy jego jakości. Biuletyn IHAR 266: 295-305.

Zamojska, J., J. Danielewicz, E. Jajor, R. Wilk, J. HoroszkiewiczJanka, D. Dworzańska, P. Węgorek, M. Korbas, P. Bubniewicz, W. Ciecierski, and J. Narkiewicz-Jodko. 2018. The influence of foliar application of silicon on insect damage and disease occurrence in field trials. Fresenius Environmental Bulletin 27: $3300-3305$.

Zieleniewicz, W., and B. Wróbel. 2018. Effect of differential nitrogen fertilization on the nutritive value of fodder mallow (Malva verticillata $\mathrm{L}$.) and maize (Zea mays $\mathrm{L}$.) eurostar variety. Journal of Research and Applications in Agricultural Engineering 63 (3): 151-156.

Zuccarini, P. 2008. Effects of silicon on photosynthesis, water relations and nutrient uptake of Phaseolus vulgaris under $\mathrm{NaCl}$ stress. Biologia Plantarum 52: 157-160.

Publisher's Note Springer Nature remains neutral with regard to jurisdictional claims in published maps and institutional affiliations. 